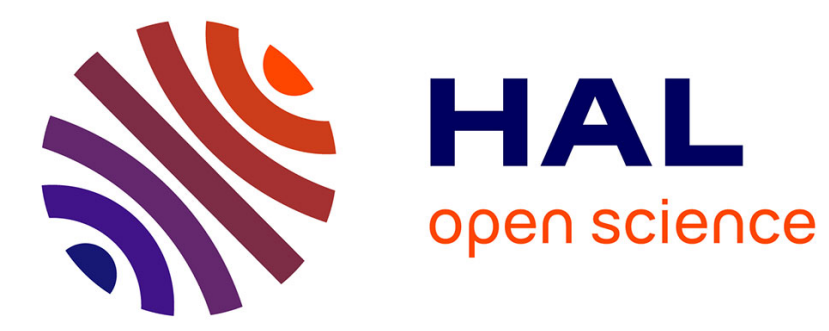

\title{
Describing and Understanding the Experience of Visitors
}

Daniel Schmitt

\section{To cite this version:}

Daniel Schmitt. Describing and Understanding the Experience of Visitors. Visiting the Visitors. An Enquiry Into the Visitor Business in Museums, Transcript Verlag, pp.55-69, 2016, 9783837632897. hal-01562405

\section{HAL Id: hal-01562405 \\ https://hal.science/hal-01562405}

Submitted on 21 Sep 2021

HAL is a multi-disciplinary open access archive for the deposit and dissemination of scientific research documents, whether they are published or not. The documents may come from teaching and research institutions in France or abroad, or from public or private research centers.
L'archive ouverte pluridisciplinaire HAL, est destinée au dépôt et à la diffusion de documents scientifiques de niveau recherche, publiés ou non, émanant des établissements d'enseignement et de recherche français ou étrangers, des laboratoires publics ou privés. 
To quote this article: Daniel Schmitt 2016, "Describing and Understanding the Experience of Visitors" in Ann Davis and Kerstin Smeds (eds), Transcript Verlag: Bielefeld, p. 55-69.

\section{DESCRIBING AND UNDERSTANDING THE EXPERIENCE OF VISITORS}

\section{Daniel Schmitt}

University of Valenciennes - France

\section{The Public in Question}

It is now quite evident that the "average museum visitor," a consumer of cultural goods and services with the expectations and behaviour of a consumer, is a myth constructed by researchers ${ }^{1}$. This pseudo-knowledge promotes simplistic messages and dramatic museographic effects while obscuring everything that visitors might wish to experience and understand as beings endowed with autonomous reason and a unique life trajectory. Without a doubt, we understand the motivations of visitors quite well, what they learn at a museum ${ }^{2}$ the significance of "influences" on them ${ }^{3}$, and the importance of the layout, special effects, and immersive technologies ${ }^{4}$. However, there are important questions to which we are only just beginning to glean the answers: can we access the intimate experience of visitors during their visit without significantly disturbing this experience? And if so, what actually happens from the perspective of visitors when they visit an exhibition? What provides meaning for them at each moment of their visit? And on what basis and how do visitors construct knowledge?

Grasping and understanding with precision the experience of visitors in the natural setting of an unguided visit may radically transform our representations of the public. As

\footnotetext{
1 Joëlle Le Marec, Publics et musées, la confiance éprouvée, Paris: L'Harmattan, 2007, 200.

2 John Falk and Lynn Dierking, The Museum Experience, Washington: Whalesback Books, 1992.

3 Jack Guichard and Jean-Louis Martinand, Médiatique des Sciences, Paris: PUF, 2000.

${ }^{4}$ Florence Belaën, "L'exposition, une technologie de l'immersion" in Médiamorphoses 9, 2003, 98-101 and Raymond Montpetit, "Expositions, parcs, sites : des lieux d'expériences patrimoniales" in Culture et Musées 5, 2005, 111-133.
} 
a result, this process may help us enrich museographic conceptions as well as the mediation of museums and exhibitions.

\section{Broaching the experience of visitors}

Researchers can describe the behaviour of a visitor in a museum. This description is scientifically acceptable insofar as it concerns the relative movement of the visitor's body in the museum space. Nevertheless, as soon as researchers begin to describe the cognitive domain of the visitor based on the observed behaviour, they commit a double error: 1) they describe the environment, significant for them and, they suppose, significant for the visitor; 2) they establish a relationship between their description of the visitor's behaviour and the cognitive domain of the latter ${ }^{5}$. The verbalization of the experience by those who live this experience is a sine qua non condition if we are to understand and share in this experience. Nevertheless, the necessity of collecting the verbalizations of visitors constitutes a delicate issue for the following reasons:

- If visitors are questioned at regular intervals during their visit, we interrupt the flow of their experience, engaging them in a reflective analysis of their actions. This practice thus modifies the activity and leads us further away from a visit in a natural setting.

- If, on the contrary, we preserve the natural setting of the visit and question visitors at the end of their tour, we collect a summarized a posteriori discourse devoid of the finesse and precision of the lived experience.

Thus, the theoretical challenge resides in bridging the temporal gap between the experience of the visitor and the verbalization of this experience, all the while preserving the precision and finesse of the description of the lived experience.

${ }^{5}$ For a detailed explanation, see Humberto Maturana and Francisco Varela, The Tree of Knowledge: The Biological Roots of Human Understanding, Boston: Shambhala Publications, 1987, 137-138. 


\section{Semiological theory of the course-of-experience}

With Humberto Maturana ${ }^{6}$, Francisco Varela developed a theory of enaction ${ }^{7}$, which allows us to overcome the aforementioned challenges. The core idea of enaction maintains that perception and action are interdependent within any organism: "Cognition is not the representation of a pregiven world by a pregiven mind but is rather the enactment of a world and a mind on the basis of a history of the variety of actions that a being in the world performs ${ }^{8}$." Perception, action, and sense of action from the perspective of the agent are thus inextricably linked to the environment in which the action takes place ${ }^{9}$.

From an enactive point of view, for example, human auditory perception and sounds are only meaningful in the emergence of a phenomenal domain involving an environment and the human system. Our environment allows variations in the air pressure, but variations in the air pressure alone cannot give rise to the phenomenon that we call noise, sound, or music. Only the structural coupling of our environment and human physiology renders the emergence of what we call sounds or music possible, and more generally, what we call auditory perception. The same applies to all of our sensory abilities. In this manner, we observe how this approach renders the objective description of the environment difficult, which mostly pertains to the phenomenological domain of the visitor. The environment that we describe is inevitably a description of our own relationship to this environment, which is in itself a relationship constructed with this very environment over time.

From the enactive perspective, visitors are not seen to be immersed in a space in which they must discover the salient and significant features; instead, they act and react to what perturbs them and what is meaningful to them, which occurs in an environment perceived through the prism of their own past, expectations, and knowledge that may be called upon at any moment. Drawing from the theoretical foundation of enaction,

${ }^{6}$ Humberto Maturana, Francisco Varela and Ricardo Uribe, "Autopoiesis: The Organization of Living Systems, its Characterization and a Model" in BioSystems 5(4), 1974, 187-196.

${ }^{7}$ Francisco Varela, Principles of Biological Autonomy, New York: Elsevier, 1979.

${ }^{8}$ Francisco Varela, Evan Thompson and Eleanor Rosch, The Embodied Mind: Cognitive Science and Human Experience, Cambridge, MA: MIT Press, 1991, 9.

${ }^{9}$ Lucy Suchman, Plans and Situated Action, Cambridge University Press, 1987. 
Theureau elaborated a semiological theory for the course-of-experience ${ }^{10}$, defined as the construction of meaning for the agent during the course of his or her action ${ }^{11}$. The theory of the course-of-experience allows us to analyze human action in its dynamic and situated (in situ) dimension in a very precise manner, in addition to the learning process that accompanies this action on the condition that it is elucidated a posteriori by whoever experiences it. When visitors are asked to comment on their actions based on the traces left by the diverse actions that they performed in a given environment, they spontaneously divide the flux of the action into discrete units that are significant from their own perspective $^{12}$. Each significant division is the manifestation of a sign, comprising six components that are both distinct and inseparable from the others:

\begin{tabular}{|l|l|}
\hline \multicolumn{2}{|c|}{ The Hexadic Sign and its Components } \\
\hline Component of the Sign & Identification of the Component \\
\hline Representamen & What is taken into account by the visitor at a given moment? \\
\hline Involvement in the situation & $\begin{array}{l}\text { How does the visitor connect with the Representamens at a given } \\
\text { moment? }\end{array}$ \\
\hline Potential actuality & What are the expectations of the visitor at a given moment? \\
\hline Referential & What knowledge is called upon by the visitor at a given moment? \\
\hline Interpretant & What knowledge does the visitor construct, whether valid or invalid? \\
\hline $\begin{array}{l}\text { Unit of course-of-experi- } \\
\text { ence }\end{array}$ & What is the minimal sequence that gives meaning to the visitor? \\
\hline
\end{tabular}

By identifying the components of these signs, we may reconstruct the meaningful dynamics of visitors' actions as well as identify the knowledge constructed by them and the emotional states linked to these actions. This process therefore allows us to describe and understand their individual microcosms, with the resultant sequences leading us to identify what is meaningful for visitors during their visit.

10 See Jacques Theureau, Le cours d'action: Méthode élémentaire, Toulouse: Octarès, 2004 ; Jacques Theureau, Le cours d'action: Méthode développée, Toulouse: Octarès, 2006; Jacques Theureau, Le cours d'action: Méthode réfléchie, Toulouse: Octarès, 2009.

11 Theureau, Le cours d'action: Méthode développée, 48.

12 Luc Ria, Carole Sève, Jacques Theureau, Jacques Saury and Marc Durand, "Beginning teacher's situated emotions: study about first classroom's experiences" in Journal of Education for Teaching, 29(3), 2003, 219-233. 


\section{Methodology: Documenting and Analyzing the Visitors' Course-of-Experience Based on a Subjective Perspective and Subjective Re-situ Interview}

Every visitor lives in an environment that is meaningful on a personal level. If this environment as it is perceived by the visitor can be reproduced, he or she may relive this experience and have the time to describe it. This ability to describe what is seen and felt as well as the thoughts that come to mind is based on reminiscence, namely the ability to re-experience in quality what has already been experienced; this is, in some ways, the effect of the "madeleine of Proust."

Overall, 41 individuals ( 21 males and 20 females) who were about to purchase a museum admission ticket were approached to participate in this research study ${ }^{13}$. To preserve a vestige of the world as perceived by each visitor, he or she was first equipped with a mini-camera to record his or her subjective visual and auditory perspective, which left the visitor free to move about without the presence of the researcher ${ }^{14}$. After a tour of around 30 minutes, the mini-camera was removed and the visitor placed in front of a video screen situated away from the site of the visit. The recording of the visit was then projected on this screen, with the visitor then being prompted to recount and comment on his or her experience of the visit. A camera, placed behind the visitor and the researcher, recorded the interview and their gestures in front of the screen. During this subjective re-situ interview, the visitor spontaneously divided his or her actions into units deemed to be significant from his or her own point of view. The descriptions and commentaries were therefore all the more precise since the video recording was conducted from the visitor's own perspective and thus emphasized reminiscence ${ }^{15}$. The subjective re-situ interview was then transcribed and analyzed using Theureau's semiological

13 Daniel Schmitt, "Expérience de visite et construction des connaissances: Le cas des musées de sciences et des centres de culture scientifique", PhD diss., University of Strasbourg, 2012, available at http://www. museographie.fr.

14 Differing from a Thinking Aloud approach, here the visitor is not asked to comment aloud during the museum visit. For details on this method, see Colette Dufresne-Tassé, Monique Sauvé, Andréa Weltzl-Fairchild, Nadia Banna, Yves Lepage and Clément Dassa, "Pour des expositions muséales plus éducatives, accéder à l'expérience du visiteur adulte. Développement d'une approche" in Canadian journal of Education 23(3), 1998, 302-315.

15 Georgiana Gore, Géraldine Rix-Lièvre, Olivier Wathelet and Anne Cazemajou “Eliciting the Tacit: Interviewing to Understand Bodily Experience," in The Interview: An Ethnographic Approach, ed. J. Skinner, London: Berg, 2012, 127-142. 
framework ${ }^{16}$. The aim was to identify what was taken into account by the visitor at each moment: what he or she looked at and did in addition to the expectations, preoccupations, and knowledge called upon, with the aim of documenting each fragment of the meaningful sequence and then reconstruct the visitor's course-of-experience.
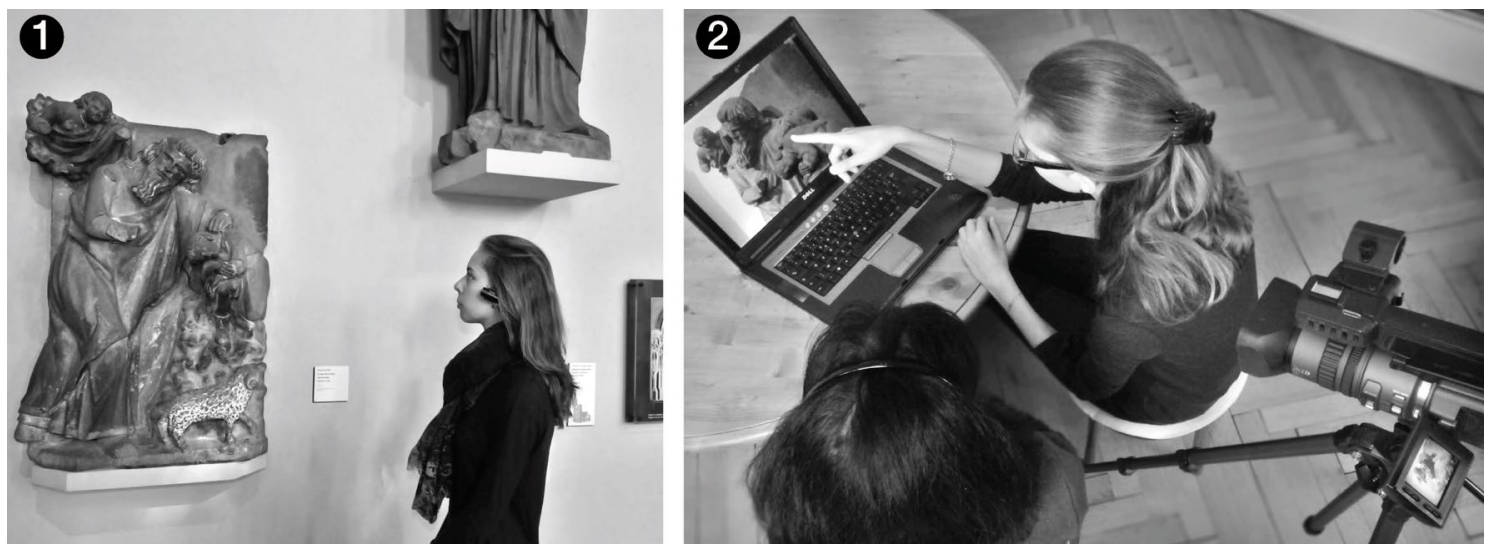

Figure 1. 1) Visitors were equipped with a mini-camera and microphone. A video recording resembling their natural visual perception was thus obtained. 2) Visitors were then invited to describe their experiences based on this film. A camera placed behind the visitor and the researcher recorded the video screen, interview, and gestures. The recording was subsequently transcribed and the hexadic signs recorded, thus allowing the reconstruction of the course-of-experience.

The recording of visitors' subjective perspective in tandem with a subjective re-situ interview allows us to access their verbal experience based on their reminiscence, without introducing significant secondary effects or manifest bias ${ }^{17}$, thus permitting their course-of-experience to be described with precision, finesse, and depth. We can therefore follow, show, and share the chain of meaningful sequences for visitors and the construction of meaning throughout their tour. The key aspect of this contribution resides in the subtle comprehension of visitors' actions, understood here as both corporal and cognitive actions. This approach reveals that knowledge is not simply transmitted in the sense of accumulating information, but rather constructed by each visitor as an adequate response to his or her expectations through harnessing the resources available in the environment or linked to his or her past. What is most striking in this approach, however, is the extraordinary wealth apparent in the visitors' course-of-experience and their inventiveness, which very often goes beyond what we imagine as museum designers or researchers.

\footnotetext{
16 Jacques Theureau, Le cours d'action: Méthode développée.

17 Schmitt, 159-170.
} 
In the CEuvre Notre-Dame Museum in Strasbourg, the room known as the rood screen presents sculptures dating from the thirteenth century. The large-scale works originate from the Cathedral of Strasbourg and loom over the visitors. The architectural volume of the room is imposing, and the mineral materials produce a strong acoustic reverberation.

Annie, aged in her 50s, works in the public service. Exhaling, she enters the rood screen room, looks at the rood screen and certain statues, exhales again, looks at the figure of the Synagogue, reads a text on an information stand, looks at the surrounding statues, reads a caption, clears her throat, approaches a statue, and reads the corresponding caption; her tour around the room lasts $3 \mathrm{~min} 27 \mathrm{sec}$. From the point of view of an observer, there is little to learn from Annie's experience because nothing enables us to interpret the tenuous signs of her actions. In contrast, with the subjective re-situ interview, Annie's actions may be divided into several coherent sequences from her perspective, which allows us to understand with precision her experience of the visit around the rood screen room.

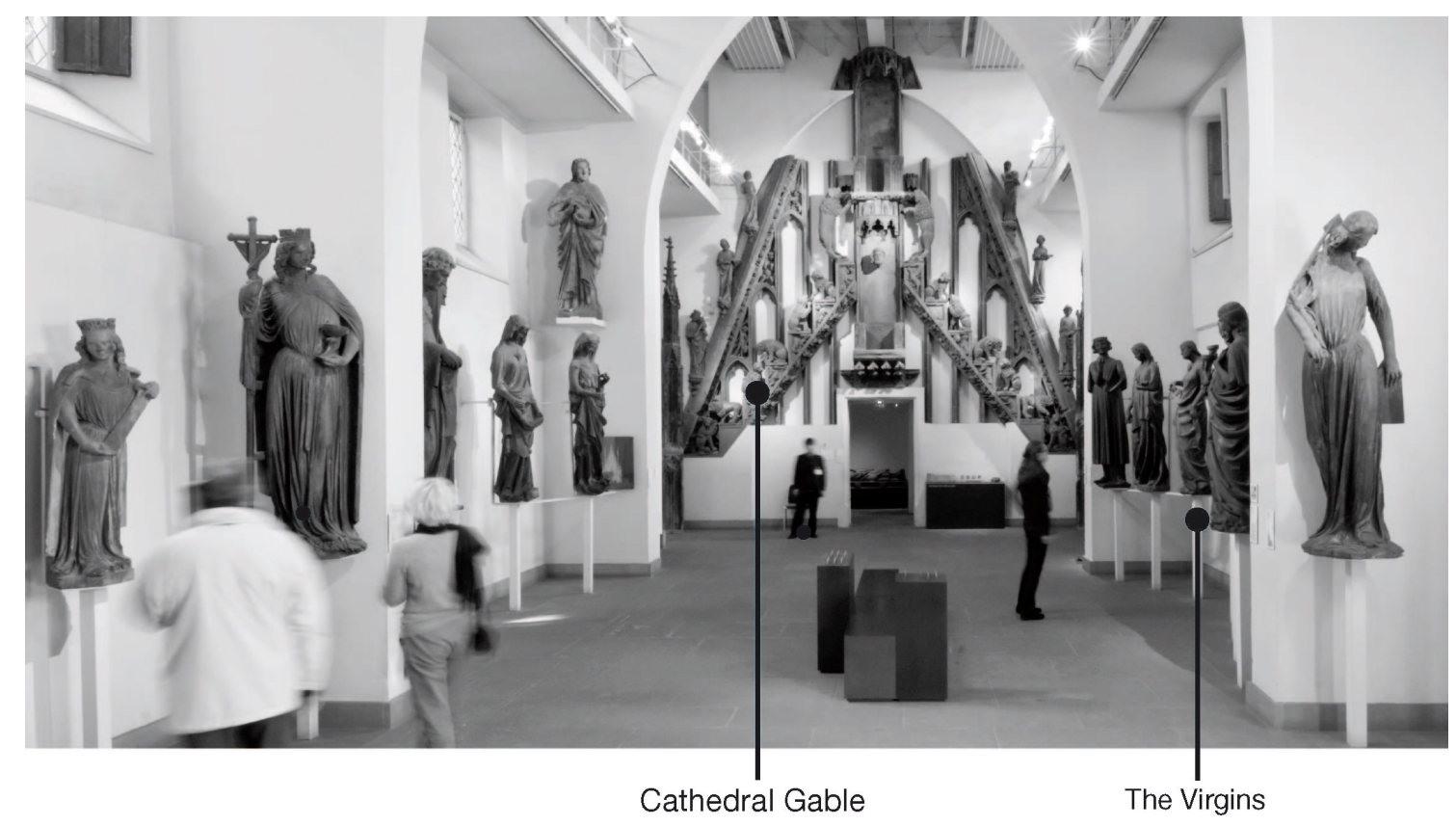


Figure 2. Perspective of the rood screen room in the CEuvre Notre-Dame Museum in Strasbourg as discovered during the sequence of the visit. "I suddenly felt a bit like I was in a ... a cathedral, but I don't at all dislike that [...] it's not morbid like most of the time, but that thing there [...] that big thing at the back is so imposing... so I didn't really know what to do... I didn't read about it, I didn't read anything" [Annie].

\section{Annie's Entrance into the Room}

Visitor:

I enter this room, and there... straight away, it's more difficult... what immediately strikes me and oppresses me, it's deep inside me, there... those figures like that... those statues are so posed. There it is, the image that oppresses me a bit, I felt it in the first room, in the pediment too. All those stones at the top, I don't know why, but it oppresses me a bit... I suddenly felt a bit like I was in a ... a cathedral, but I don't at all dislike it. But l've got a big problem at the moment with anything to do with churches, the images, etc., but l'm not even in [a church], because there, there's statues, stones, and it's not... It's not morbid like most of the time, but that thing there... That's what I find, what I found in this room, it's that ... everything seemed so posed... well, they're posed, they're... The room's not meant for that, but that's the feeling I have... and those things that are so posed like that and that big thing at the back there, it's so imposing... But there you go, I didn't really know what to do... I didn't read about it, I didn't read anything.

Researcher: What's the big imposing thing?

Visitor:

The big imposing thing at the back there, all of it (Annie indicates a sculpture on the screen with her finger) < the pediment > yes, the pediment, thank you. So now, what l'm going to do, l'm going to... I'm going to go and have a look, in any case, take an interest in what's there, the statues, what are they, what do they mean, where do they come from, where do they take me, you know? Afterwards, I'm going to take a look around, I'll look ... do I like the faces ... where am I... how's it made...

Researcher: What is guiding you?

Visitor:

What guides me are the forms, finding something that interests me like that, something that attracts me, and it's the statues and so what guides me in these statues it's... wait, l'll look < the cartels > yes, that one there, I know the blindfolded statue, but I couldn't tell you what it is, but what interested me before was... the image didn't stop above it, but it's what seems less religious. After that, what guides me is the forms, the statues... that means more to me than anything else, I'm attracted to that one at the front and then afterwards... I become interested in the Wise Virgins over there, which are also quite imposing. So you see, it's the Wise Virgins.

A few minutes later, we return to the entry of the rood screen room.

Researcher: l'd like to return to this initial view. Do you remember... emotionally this room from the entrance?

Visitor:

Ah, this here? Yes, I exhaled... All I could say is "wow," that's what I did.

Researcher: Meaning what?

Visitor:

Um, meaning that... for me it meant... in fact, I don't know, how can I explain... It was just imposing, it was... just like it resembled something to do with a... a church, religion, all that I find so... all that's heavy.

Researcher: What's meaningful for you here, I mean, the element that you perceive in this space?

Visitor: It's the prominence of the back [of the room]. Yes, it's the prominence of the back, it's... all of that there violently imposes itself on me, you see. 
Researcher: $\quad$ And do you remember when you entered, you exhaled $<$ yes $>$. Do you remember your expectations just before entering this space, did you hope something would happen, and if so, what?

Visitor: $\quad$ Yes, I... let's say it means... not that, but this... you see, not that, but this, I mean l'd prefer to be accompanied. Already, it was a journey for me because it really focused on religion, no? What I want to say is that it's mostly that, l'd prefer to be accompanied, to make it lighter.

\section{Components of the Signs}

Representamens

An oppressive form

A big imposing thing at the back

Statues, faces of statues

Forms of statues

Involvement in the situation

Feeling oppressed

Feeling like being in a religious building rather than a museum

Taking an interest in statues to see whether a narrative is possible

Moving away from a religious narrative

Looking at the forms

Potential actualities

Expectations associated with entering into a narrative, being accompanied Expectations associated with seeking less religious forms

Expectations associated with identifying forms that attract and guide

\section{Referentials}

Most of the time, churches are morbid places

Units of the course-of-experience

Immediate, negative impression

Avoiding religion by transforming the statues into forms, into sculptures (nonreligious)

Interpretant

Reinforcing knowledge: "This museum resembles a church" 


\section{Annie's Course-of-Experience}

Annie moves from a small space, a sort of vestibule, into a vast, luminous room. She perceives the rood screen at the back of the room (Representamen) and immediately feels "oppressed": the place is "oppressive" and things seem "posed" (Involvement). Walking down the steps toward the rood screen, she lets out a huge sigh, clearly audible on the subjective perspective recording. This time, she sees "a big thing at the back" (Representamen), the gable of the rood screen, "the object at the back" that she fails to identify. This room oppresses her (Involvement). She no longer knows whether she is in a museum or a cathedral. She seeks to immerse herself in the narrative (Potential actuality), but the proposed narrative is, in her opinion, a religious narrative, and for her, religion is "heavy and oppressive." Her encounter with the gable of the rood screen is negative. Annie hopes to escape this feeling by "suppressing the religious elements and moving toward something more human." For her, churches are "morbid places" (Referential). She expects the narrative of a museum, not a religious narrative (Potential actuality); as a result, she feels confined in the space and seeks to free herself from it (Potential actuality). She looks for objects that attract her, objects with which she can construct or enter into a narrative that suits her. She constructs knowledge: "this museum resembles a church" (Interpretant).

\section{Annie's Visit around the Room}

Visitor:

I'm looking, yes, but I don't really know what I'm looking for, but l've got an idea. Either I'm attracted to a form like that, which is surprising because it's different, because it's someone with no legs, because... I know, because the form of the sculpture interests me. Or it's because of something else... that reminds me, I know, like the Foolish Virgins. I know them because I saw them on the door before, there are the Wise and the Foolish. I saw the Wise so I'm looking for the Foolish. So perhaps it's an idea or a form that interests me more than anything else and I'm always trying to feel where I am, what it's telling me, etc. It doesn't always tell me something, I need more time... so there you go... ah yes, that one also attracts me, what's that one there, after that, it reminds me...

Researcher: It doesn't attract you for very long because you keep moving, you drift past it.

Visitor:

Yes, for now l'm drifting, in fact... it's seems to be my way of doing things, I mean, I'm... I need more time, I mean, for the moment I'm drifting, looking where I am, and then I'll go back, that is, if I could go back and be interested for longer. I keep returning to the idea of the vestibule, I mean, the need to be guided, to feel like I'm experiencing something, which is not the case at the moment, so if you like, it's as if... as if I were listening to what the stones were telling me, where they're taking me because it's the stones, especially what I have to do with them, where they're taking me. Later, l'll go back by going deeper. You see, for the moment, I don't have... how to say it, I'm in the middle of feeling where I am and what the stones are telling me, roughly speaking ... That's why I drift past, yes, that's why...

Researcher: But how do you know that they're telling you something, how do they speak to you, and when do they tell you something?

Visitor:

The stones, they tell me something through their form, they tell me something through their presence, well, at the moment, I'm at the stage where I feel like I'm playing it by ear. Then I turn back to the dogs, I liked the dogs, so it's 
something to do with the sculpture, it's something that's... that goes beyond my initial idea about religion, which isn't easy for me at the moment, in fact, all that it means. I don't connect with it, you see, so it's a bit like that. I'm going more by the appearance... the appearance of the sculptures, you see, sculptures made of stone. So there you go, I don't really like the pediment so I don't stop, it's my first impression, I don't stop much, and...

Researcher: Why don't you like it?

Visitor:

Because it reminds me of a church, it reminds me of something that is extremely formal in religion, which at the moment really tends to... to repel me more than attract me. So l'm going to do what guides me... Everything slightly different from traditional religion, for example, that statue over there attracts me because it's different from the others, you see, that's how I'm going to do things. So l'm going to go and look at what it is.

\section{Components of the Signs}

Representamens

Forms without reference to the religious domain

Statues reified in stone

Involvement in the situation

Seeking to enter into a non-religious narrative

Drifting so as to gather her bearings, finding the right place, and returning / Verifying whether a narrative about stones is possible / Avoiding and removing herself from the religious domain

Potential actualities

Expectations associated with a narrative outside of the religious domain Expectations associated with feeling guided

\section{Referentials}

I am familiar with cathedrals or certain elements in cathedrals

Sculpture (art) can transcend religion

Units of the course-of-experience

Drifting-identifying stones and forms

Interpretant

The action of drifting- identifying allows her to give meaning to the stones / ongoing construction of meaning through the "sculptural" dimension 


\section{Annie's Course-of-Experience}

To escape the oppressive feeling, Annie visually avoids the rood screen and focuses (Involvement) on the statues. She is still searching for an anchor in order to enter into a narrative: "what does it mean, where does it take me" (Potential actuality). But then she finds her guidance- "it's the forms" (Representamen) and "whatever seems less religious" (Potential actuality)—so she stops to read the graphical information panel presented on the form of a lectern. A novel strategy thus begins to take shape. In a certain way, Annie "reuses" her visual field (new Involvement) so that she no longer sees churches, gables, and statues, but simply forms and stones, "something that transcends the idea of religion," and eventually, "the stone sculpture" (Representamen). Nothing provides her with an anchor, so she drifts past the stones and forms (Involvement) with the expectation of finding works that allow her to enter into a narrative (Potential actuality). This reification of the religious statues made of stone, fragments, or forms and this transformation of the nature of Representamens associated with the Potential actuality of avoidance (avoiding the religious domain) is the creative approach used by Annie in the hope of "entering into a narrative" and giving meaning to these stones. Annie thus finds a novel solution through narrowing her visual field. We observe her modifying her perceptual frame to construct Representamens in the form of non-religious statues, and with such a creative approach, she is able to cope with this environment and render it bearable for lack of rendering it "likeable."

\section{Input and Perspectives}

The analysis of visitors' course-of-experience using a subjective re-situ interview allows us to show that every element, every exhibit, and every work, as perceived as an evident thing-in-itself offered for all eyes to see, emerges through a subtle and complex cognitive and corporal process. This process engages visitors by way of what constitutes them and reflects their relationship to the world, their unique physiological, cognitive, and perceptive capacities, past, knowledge, expectations, and desire to identify with "something" through an interaction with other members of the group, who similarly possess their own individual and unique capacities.

This epistemic framework and method allow a subtle comprehension of the experience of a museum visit in a natural situation. For the most part, the catalogue of these surprisingly diverse experiences reveals an ongoing preoccupation, which incites us to rethink the nature of visitors' relationship to the environment that constitutes a museum space, works, knowledge, and displays. What matters to visitors is their ability to connect to this environment in a manner that suits them, by developing adequate responses to 
questions that they ask themselves at every instant, which are independent of the intentions of the museum. As soon as they obtain a response to their preoccupation, they know something that is meaningful to them and thus gain a sense of pleasure. This approach, centered on the categorization of experiences rather than the categorization of publics, has the potential to durably transform, enlarge, and enrich museographic practices, the type of contents on offer, and their dynamic mediation. Finally, the enrichment of the experiential palette proposed by museums should thus increase the satisfaction of visitors in both quality and proportion.

\section{Works Cited}

Belaën, Florence. "L'immersion dans les musées de science : médiation ou séduction ?" Culture \& Musées, $n^{\circ} 5$ (2005): 91-110.

Dufresne-Tassé, Colette, Monique Sauvé, Andréa Weltzl-Fairchild, Nadia Banna, Yves Lepage and Clément Dassa. "Pour des expositions muséales plus éducatives, accéder à l'expérience du visiteur adulte. Développement d'une approche," in Canadian journal of Education 23(3), 1998, 302-315.

Falk, John, and Lynn Dierking. The Museum Experience. Washington, Whalesback Books, 1992.

Gore, Georgiana, Géraldine Rix-Lièvre, Olivier Wathelet and Anne Cazemajou. "Eliciting the Tacit: Interviewing to Understand Bodily Experience" The Interview: An Ethnographic Approach. London, Berg (2012):127-142.

Guichard, Jack and Jean-Louis Martinand. Médiatique des Sciences. Paris, PUF, 2000.

Le Marec, Joëlle. Publics et musées, la confiance éprouvée. Paris, L'Harmattan, 2007.

Maturana, Humberto, Francisco Varela and Ricardo Uribe. "Autopoiesis: The Organization of Living Systems, its Characterization and a Model” in BioSystems 5(4), 1974, 187-196.

Maturana, Humberto, and Francisco Varela. The Tree of Knowledge: The Biological Roots of Human Understanding. Boston, Shambhala Publications (1987): 137-138.

Montpetit, Raymond. "Expositions, parcs, sites : des lieux d'expériences patrimoniales," in Culture et Musées 5, 2005, 111-133.

Ria, Luc, Carole Sève, Jacques Theureau, Jacques Saury and Marc Durand. "Beginning Teacher's Situated Emotions: A Study of First Classroom Experiences," Journal of Education for Teaching, vol. 29, n³ (2003): 219-233.

Schmitt, Daniel. "Expérience de visite et construction des connaissances: Le cas des musées de sciences et des centres de culture scientifique", PhD diss., University of Strasbourg, 2012, available at http://www.museographie.fr.

Suchman, Lucy. Plans and Situated Action. Cambridge University Press, 1987. 
Theureau, Jacques. "Course-of-Action Analysis and Course-of-Action-Centered Design," in Handbook of Cognitive Task Design. Mahwah, Lawrence Erlbaum Associates, 2003.

—. Le cours d'action: Méthode élémentaire. Toulouse, Octarès, 2004.

—. Le cours d'action: Méthode développée. Toulouse, Octarès, 2006.

—. Le cours d'action: Méthode réfléchie. Toulouse, Octarès, 2009.

Varela, Francisco. Principles of Biological Autonomy. New York, Elsevier, 1979.

Varela, Francisco, Evan Thompson and Eleanor Rosch. The Embodied Mind: Cognitive Science and Human Experience. Cambridge, MIT Press, 1991. 